\title{
Search for sources of wide-spectrum resistance to Fusarium oxysporum f. sp. basilici isolates in accessions of Ocimum species
}

\author{
A. Reis $\cdot$ L. S. Boiteux $\cdot$ R. F. Vieira
}

Received: 9 July 2007 / Accepted: 22 April 2008/Published online: 2 August 2008

(C) The Phytopathological Society of Japan and Springer 2008

\begin{abstract}
Ocimum (Lamiaceae) is an important plant genus, with many species used for food flavorings and for essential oils. Fusarium wilt (Fusarium oxysporum f. sp. basilici, FOB) is the most important disease of basil (O. basilicum L.). Twenty-five accessions of $O$. basilicum, five of $O$. americanum and two of $O$. campechianum were initially evaluated for resistance to one FOB isolate (named as FOB-1). Eight accessions (identified as resistant to FOB1) and one susceptible control were reevaluated to FOB-1 and four other FOB isolates of distinct geographic origins. The FOB isolates varied in aggressiveness and interacted differentially with the Ocimum accessions. Two accessions of $O$. americanum, one of $O$. campechianum, and one of $O$. basilicum had high levels of resistance to all five FOB isolates. The Ocimum germplasm identified here could represent useful sources of resistance genes for developing cultivars with wide-spectrum resistance (i.e., effective against a broad range of FOB isolates). In addition, having a set of potential differential accessions might be useful for large-scale analysis of FOB isolates to demonstrate the presence of physiological races in the Ocimum-FOB pathosystem.
\end{abstract}

Keywords Fusarium wilt - Ocimum .

Pathogen variability · Host plant resistance

\footnotetext{
A. Reis $(\bowtie) \cdot$ L. S. Boiteux

National Center for Vegetable Crops Research (CNPH), Embrapa Vegetable Crops (Hortaliças), Caixa Postal 218, Brasília-DF 70359-970, Brazil

e-mail: ailton@cnph.embrapa.br

R. F. Vieira

Embrapa Genetic Resources and Biotechnology (Cenargen),

CP 02372, Brasília-DF 70770-900, Brazil
}

\section{Introduction}

The genus Ocimum (family Lamiaceae) comprises $\sim 30$ species native to the tropics and subtropics in both New and Old World areas (Paton 1992; Ryding 1994; Albuquerque and Andrade 1998). Natural interspecific and intraspecific hybridization are the major factors associated with the large phenotypic variability observed in Ocimum. This genus is characterized by numerous species, botanical varieties, cultivars, and chemotypes, which are accessions and/or species with distinct blends of aromatic volatile oils (Vieira and Simon 2006).

Sweet basil (Ocimum basilicum L.) is a popular culinary herb, used either fresh or dried to flavor soups, pickles, sauces and salads (Özcan and Chalchat 2002). Another economic use of basil is the extraction of essential oils for use in fragrances, traditional medicine, cosmetics and pharmaceuticals (Vieira and Simon 2000; Silva et al. 2005). Sweet basil is a global crop because of its adaptability to a range of distinct environmental conditions around the world (Vieira and Simon 2000; Özcan and Chalchat 2002). Currently, the most important commercial plantings of basil are concentrated in the Mediterranean region of Italy, France, Spain, and Israel and in California, USA (Ryding 1994; Garibaldi et al. 1997; Özcan and Chalchat 2002). In Brazil, the cultivation of sweet basil has gradually increased over the years to supply the growing demand (Silva et al. 2005). However, as expected, the incidence of diseases is increasing at the same time.

Fusarium wilt, caused by isolates of Fusarium oxysporum $\mathrm{f}$. sp. basilici (FOB), is one of the main problems for sweet basil because of its very destructive nature. The pathogen has a narrow host range and is considered specific for basil (Keinath 1994; Garibaldi et al. 1997; Reuveni et al. 1997). FOB has been disseminated to new growing 
areas throughout the world via imported seeds (Elmer 2001) and is now present in most countries where sweet basil is cultivated (Grasso 1975; Wick and Haviland 1992; Katan et al. 1994; Keinath 1994; Garibaldi et al. 1997; Guirado-Moya et al. 2002; Swart and van Niekerk 2003; Summerell et al. 2006).

In Brazil, Fusarium wilt of sweet basil was recently been reported (Reis et al. 2007) and may become a major concern for basil growers if adequate disease control measures are not implemented. As demonstrated for several other Fusarium wilt diseases with distinct host plants, the most effective control strategy is the deployment of resistant cultivars (Garibaldi et al. 1997; Reuveni et al. 1997; Reis et al. 2004; Chaimovitsh et al. 2006). Commercial cultivars with genetic resistance to FOB are available in some countries (Garibaldi et al. 1997; Dudai et al. 2002; Biris et al. 2004; Chaimovitsh et al. 2006). However, so far no cultivars that are resistant to the pathogen and adapted for cultivation in Brazil are commercially available. In addition, the sources of resistance reported elsewhere need to be tested for their usefulness in Brazilian breeding programs by challenging these sources with the FOB isolates that prevail in Brazil. The major objective of the present work was to evaluate an Ocimum germplasm collection searching for useful wide-spectrum sources of resistance to Fusarium to a range of five distinct FOB isolates.

\section{Materials and methods}

\section{Fusarium oxysporum f. sp. basilici isolates}

Five FOB isolates were used in the present study. Two isolates (named as FOB-1 and FOB-2) were obtained from wilted basil plants collected in two commercial fields in Brazlândia (Federal District), Brazil. Two other isolates (FOB-4 and FOB-5) were isolated from commercial seeds from distinct geographic areas. One other isolate, obtained from basil (FOB-3), was provided by the Mycology Laboratory of Embrapa Genetic Resources and Biotechnology (Cenargen, Brasília-DF, Brazil).

Screening for resistance to FOB-1 isolate of $F$. oxysporum f. sp. basilici (assay 1)

Screening for resistance was carried out in a greenhouse with air temperature varying from 20 to $32^{\circ} \mathrm{C}$ at Embrapa Vegetable Crops in Brasília-DF, Brazil. In the first assay, 32 accessions comprising $25 O$. basilicum, five $O$. americanum, two $O$. campechianum accessions (Table 1) were evaluated for reaction to Brazilian isolate FOB-1 of F. oxysporum f. sp. basilici. Plants were sown in styrofoam trays with 128 cells, filled with sterile Plantmax ${ }^{\circledR}$ (Eucatex,
Brazil) substrate. Seedlings with the first two pairs of true leaves fully opened (about 25 days after planting) were removed from the tray cells, and the root system was gently washed with a spray of water. The apical portion of the root system $(\sim 2 \mathrm{~cm})$ was cut off with a pair of scissors. The remaining portion of the root system was dipped in a conidial suspension $\left(10^{6}\right.$ conidia/mL) for $1 \mathrm{~min}$. Conidia were produced in potato dextrose broth under standard conditions (Reis et al. 2004).

Four plants of each accession were mock inoculated with water and used as the control group. Just after inoculation, the seedlings were transplanted to $1.5 \mathrm{~kg}$ plastic pots, four plants per pot with sterile soil and maintained in the same greenhouse. The experimental plots (three pots each) were replicated three times in a randomized block design.

Disease severity was assessed 28 days after inoculation using an ordinal scale (1-5) with $1=$ free of symptoms, $2=$ without wilt symptoms but having conspicuous vascular browning, 3 = vascular browning and wilt symptoms, $4=$ severe wilting associated with the presence of foliar necrosis and chlorosis, and $5=$ plant death (Reis et al. 2004). The response of individual plants within each accession was then converted to a disease index by dividing the sum of the individual plant grades over the total number of plants. Disease index values were analyzed using analysis of variance (ANOVA), and the means were compared using the Scott and Knott (1974) test $(P \leq 0.05)$. Based on these criteria, one of the five reaction classes [highly resistant (HR), resistant (R), low levels of resistance (LR), susceptible (S) and highly susceptible (HS)] was arbitrarily assigned to each accession.

Screening for resistance of a select group of accessions to five $F$. oxysporum f. sp. basilici isolates (assay 2)

A subgroup of eight Ocimum accessions identified as responding with either $\mathrm{HR}$ or $\mathrm{R}$ to FOB-1 in assay 1 were reevaluated for reaction to this isolate and for reactions to four F. oxysporum f. sp. basilici isolates (FOB-2-FOB-5). The previously reported susceptible cultivar Dark Opal (Reis et al. 2007) was used as a control. The experimental plots and evaluation criteria in assay 2 were essentially the same as described for assay 1.

\section{Results}

In the first assay, 32 accessions from three Ocimum species were evaluated against one Brazilian isolate of $F$. oxysporum f. sp. basilici (Reis et al. 2007). The isolate was highly virulent to the susceptible control Dark Opal, indicating adequate inoculum viability. The Scott and Knott (1974) test grouped the accessions into five classes of 
Table 1 Reaction of 32 Ocimum accessions from the collection of the National Center for Vegetable Crops (CNPH) to one isolate of Fusarium oxysporum f. sp. basilici (FOB-1) obtained in Brasilia, Federal District, Brazil

\begin{tabular}{|c|c|c|c|c|}
\hline Accession & Species & CNPH Code & Disease Index ${ }^{a}$ & Reaction $^{\text {b }}$ \\
\hline Italian Large Leaf & O. basilicum & CNPH-001 & $5.00 \mathrm{~A}$ & HS \\
\hline Dark Opal & O. basilicum & CNPH-002 & $5.00 \mathrm{~A}$ & HS \\
\hline Red Osmin & O. basilicum & CNPH-003 & $5.00 \mathrm{~A}$ & HS \\
\hline Red Rubin & O. basilicum & CNPH-004 & $5.00 \mathrm{~A}$ & HS \\
\hline BRA-0132 & O. basilicum & CNPH-026 & $5.00 \mathrm{~A}$ & HS \\
\hline BRA-0230 & O. basilicum & CNPH-028 & $5.00 \mathrm{~A}$ & HS \\
\hline Toscano Lettuce Leaf & O. basilicum & CNPH-011 & $5.00 \mathrm{~A}$ & HS \\
\hline Minete Anão & O. basilicum & CNPH-013 & $5.00 \mathrm{~A}$ & HS \\
\hline BRA-0264 & O. basilicum & CNPH-029 & $4.92 \mathrm{~A}$ & HS \\
\hline BRA-0221 & O. basilicum & CNPH-027 & $4.75 \mathrm{~A}$ & HS \\
\hline Roxo CNPH & O. basilicum & CNPH-039 & $4.75 \mathrm{~A}$ & HS \\
\hline BRA-0331 & O. basilicum & CNPH-035 & $4.67 \mathrm{~A}$ & HS \\
\hline Roxo Taguatinga & O. basilicum & CNPH-017 & $4.50 \mathrm{~A}$ & HS \\
\hline Roxo Goiânia & O. basilicum & $\mathrm{CNPH}-020$ & $4.50 \mathrm{~A}$ & HS \\
\hline Roxo de Tijucas & O. basilicum & CNPH-040 & $4.50 \mathrm{~A}$ & HS \\
\hline BRA-0256 & O. basilicum & CNPH-038 & $4.33 \mathrm{~A}$ & HS \\
\hline Alfavaca Basilicão & O. basilicum & CNPH-012 & $4.08 \mathrm{~B}$ & $\mathrm{~S}$ \\
\hline BRA-0388 & O. basilicum & CNPH-034 & $3.67 \mathrm{~B}$ & $\mathrm{~S}$ \\
\hline Vargem Bonita & O. basilicum & CNPH-014 & $3.33 \mathrm{~B}$ & $\mathrm{~S}$ \\
\hline BRA-0108 & O. americanum & CNPH-025 & $3.17 \mathrm{C}$ & LR \\
\hline Basílico Itália & O. basilicum & CNPH-037 & $3.08 \mathrm{C}$ & LR \\
\hline BRA-0337 & O. basilicum & CNPH-032 & $3.00 \mathrm{C}$ & LR \\
\hline Genovese & O. basilicum & CNPH-036 & $3.00 \mathrm{C}$ & LR \\
\hline BRA-0299 & O. basilicum & CNPH-030 & $2.25 \mathrm{D}$ & $\mathrm{R}$ \\
\hline BRA-0361 & O. атеricanum & CNPH-033 & $2.17 \mathrm{D}$ & $\mathrm{R}$ \\
\hline Gecom & O. basilicum & CNPH-015 & $2.17 \mathrm{D}$ & $\mathrm{R}$ \\
\hline Cameo & O. basilicum & CNPH-016 & $1.75 \mathrm{E}$ & HR \\
\hline BRA-0060 & O. americanum & CNPH-024 & $1.42 \mathrm{E}$ & HR \\
\hline Alfavaca-2 & O. campechianum & CNPH-041 & $1.37 \mathrm{E}$ & HR \\
\hline Alfavaca-1 & O. campechianum & CNPH-008 & $1.33 \mathrm{E}$ & HR \\
\hline Manjericão SC & O. americanum & CNPH-009 & $1.00 \mathrm{E}$ & HR \\
\hline Manjericão GO & O. americanum & CNPH-010 & $1.00 \mathrm{E}$ & HR \\
\hline
\end{tabular}

a Assessed at 28 days after inoculation on a scale from 1 to 5 with $1=$ plant free of symptoms to $5=$ dead plant. Means followed by the same letter are not different among themselves according to the Scott and Knott (1974) test $(P \leq 0.05)$

b Based upon the Scott and Knott (1974) test, reaction classes [highly resistant $H R$, resistant $R$, low levels of resistance $L R$, susceptible $S$ and highly susceptible $H S$ ] were assigned to each accession

reaction to FOB: $25.7 \%$ of the accessions were $\mathrm{HR}, 8.6 \%$ were $\mathrm{R}, 11.4 \%$ were $\mathrm{LR}, 8.6 \%$ were $\mathrm{S}$ and $45.7 \%$ were $\mathrm{HS}$ (Table 1). The group with the HR response to isolate FOB-1 was composed of the following nine accessions: O. americanum (CNPH-009, CNPH-010, and BRA-0060), O. campechianum (CNPH-008 and CNPH-041) and $O$. basilicum Cameo (Table 1). The R and LR groups were composed of seven accessions: five $O$. basilicum accessions (BRA-0299, BRA-0337, Basílico Itália, Gecom and Genovese) and two O. americanum accessions ('BRA-0361' and 'BRA-0108').
A subgroup of accessions with HR, R or LR responses to FOB-1 was reevaluated in a second assay with this isolate and four other isolates of the pathogen. (Figs. 1a, b and 2a, b). The analyses of interaction among accessions and isolates indicate that four Ocimum accessions (BRA-0060, BRA0299, BRA-0361 and CNPH-008) displayed resistance to all five isolates. The $O$. basilicum cv. Dark Opal (the susceptible control) was susceptible to all five FOB isolates (Fig. 1a). Ocimum americanum and O. campechianum had high levels of resistance to all five FOB isolates. Ocimum basilicum 'BRA-299' had levels of resistance 

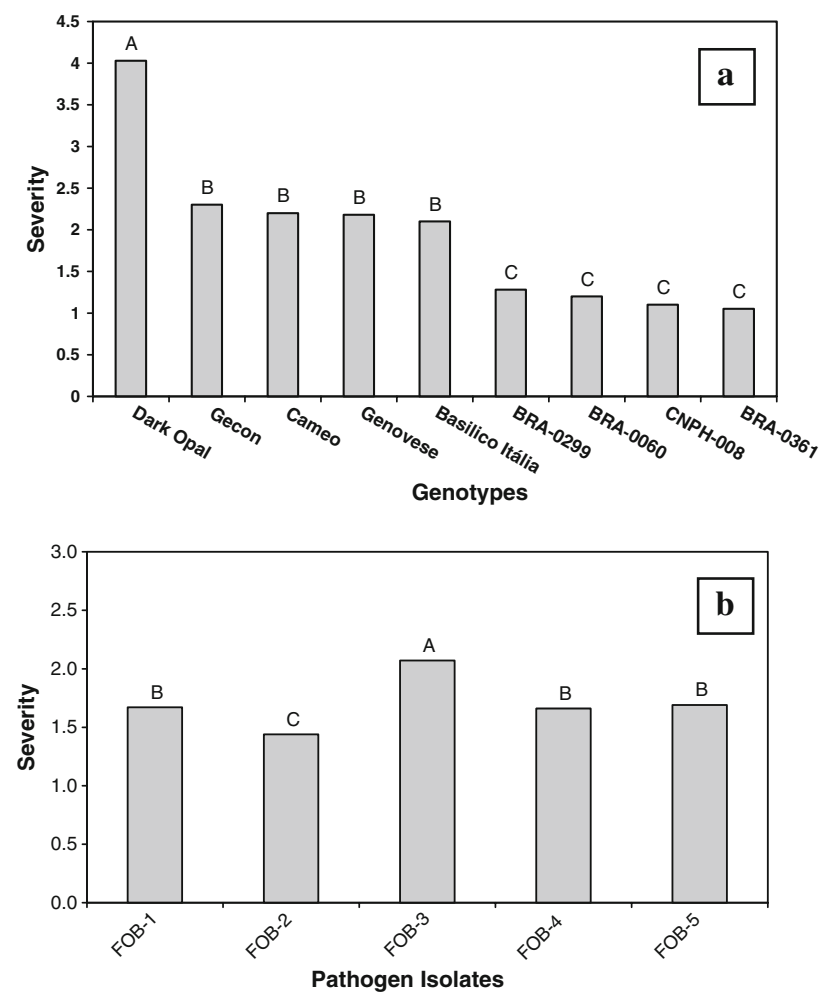

Fig. 1 Reaction of Ocimum accessions to five Fusarium oxysporum $\mathrm{f}$. sp. basilici (FOB) isolates (a), and the overall behavior of the five pathogen isolates on these Ocimum accessions (b). Severity scale from $1=$ free of symptoms to $5=$ plant death. Columns with the same letter do not different among themselves according to the Scott and Knott (1974) test $(P \leq 0.05)$

similar to those of $O$. americanum and $O$. campechianum. The $O$. basilicum accessions Cameo, Genovese, Gecon and Basílico Itália varied in their reactions to some FOB isolates (Fig. 2a).

On the pathogen side, the FOB isolates were subdivided into three groups according to their aggressiveness (sensu Nelson 1978). Isolate FOB-3 was the most aggressive; isolate FOB-2 was the least aggressive, whereas FOB-1, FOB-4 and FOB-5 were intermediate in their aggressiveness (Fig. 1b). Isolate FOB-3 had a peculiar reaction characterized by the highest levels of aggressiveness toward cvs. Genovese and Basílico Itália (Fig. 2a, b).

\section{Discussion}

Fusarium wilt is one of the most important diseases of sweet basil and can be highly destructive especially under warm temperature and high humidity (Garibaldi et al. 1997). Disease control using chemical and cultural strategies may thus be ineffective in most areas of Brazil, which has a predominance of climatic conditions that favor field epidemics of FOB. Because Fusarium wilt has the potential to become one of the most important diseases of sweet basil in Brazil, the identification of accessions with genetic resistance to FOB is needed for the development of commercial cultivars that are well adapted to Brazilian conditions. Ideally, these cultivars would have high levels of FOB resistance and a distinct blend of essential oils (Vieira and Simon 2006).

Among the $25 \mathrm{O}$. basilicum accessions, only one was highly resistant (HR), and only two accessions had a resistant $(\mathrm{R})$ reaction against the isolate FOB-1. In fact, most accessions of $O$. basilicum were highly susceptible. Among the five $O$. americanum accessions two were HR, one $\mathrm{R}$ and two LR, with none of them being either $\mathrm{S}$ or HS. The two $O$. campechianum accessions were HR. Based upon sample size, these results suggest that resistance factors to FOB appear to be more common in $O$. campechianum and $O$. americanum than in $O$. basilicum germplasm. In germplasm screening in the USA, no source of resistance was found in a group of $15 \mathrm{O}$. basilicum cultivars (Reuveni et al. 1997). However, sources of resistance to local FOB isolates were identified in $O$. $b a$ silicum cultivars in Greece (Biris et al. 2004) and Israel (Chaimovitsh et al. 2006). Therefore, the group of Ocimum accessions with $\mathrm{HR}$ and $\mathrm{R}$ reactions to distinct pathogen isolates could represent alternative germplasm sources for sweet basil breeding programs. In addition, the cv. Genovese seems to be a source of "partial resistance" (sensu Parlevliet 1979) to FOB because it had an intermediate response to Greek (Biris et al. 2004) as well as Brazilian isolates (present study).

The analyses of the interactions between Ocimum and FOB isolates revealed accessions with high levels of resistance to all five isolates, and Dark Opal has potential as a universal susceptible standard for the FOB isolates used in the present study. However, it is interesting to note that in Greece cvs. Dark Opal and Toscano Lettuce Leaf were rated as resistant (Biris et al. 2004), whereas in our study, they were classified as highly susceptible. Some $O$. basilicum accessions such as Cameo, Genovese, Gecon and Basílico Itália displayed variable levels of interaction with FOB isolates.

In relation to pathogen variability, our results clearly indicate that the five FOB isolates differed in aggressiveness levels, falling into three well-defined groups. The variability of FOB isolates has already been identified either at DNA level or by the presence of distinct compatibility groups (for a recent review, see Summerell et al. 2006). However, there is yet no clear indication of the potential presence of distinct physiological races among FOB isolates. Biris et al. (2004) speculated that different countries may have different FOB races based upon the responses of a group of cultivars to a local FOB isolate compared with those reported in the literature. Our results 
Fig. 2 Severity of five isolates of Fusarium oxysporum f. sp. basilici (FOB) on nine Ocimum accessions, grouping (a) the reactions of host genotype against all the isolates and the reverse, grouping (b) the reactions of all host genotypes to an isolate. Severity scale from $1=$ free of symptoms to $5=$ plant death. Columns with the same letter do not different among themselves according to the Scott and Knott (1974) test $(P \leq 0.05)$

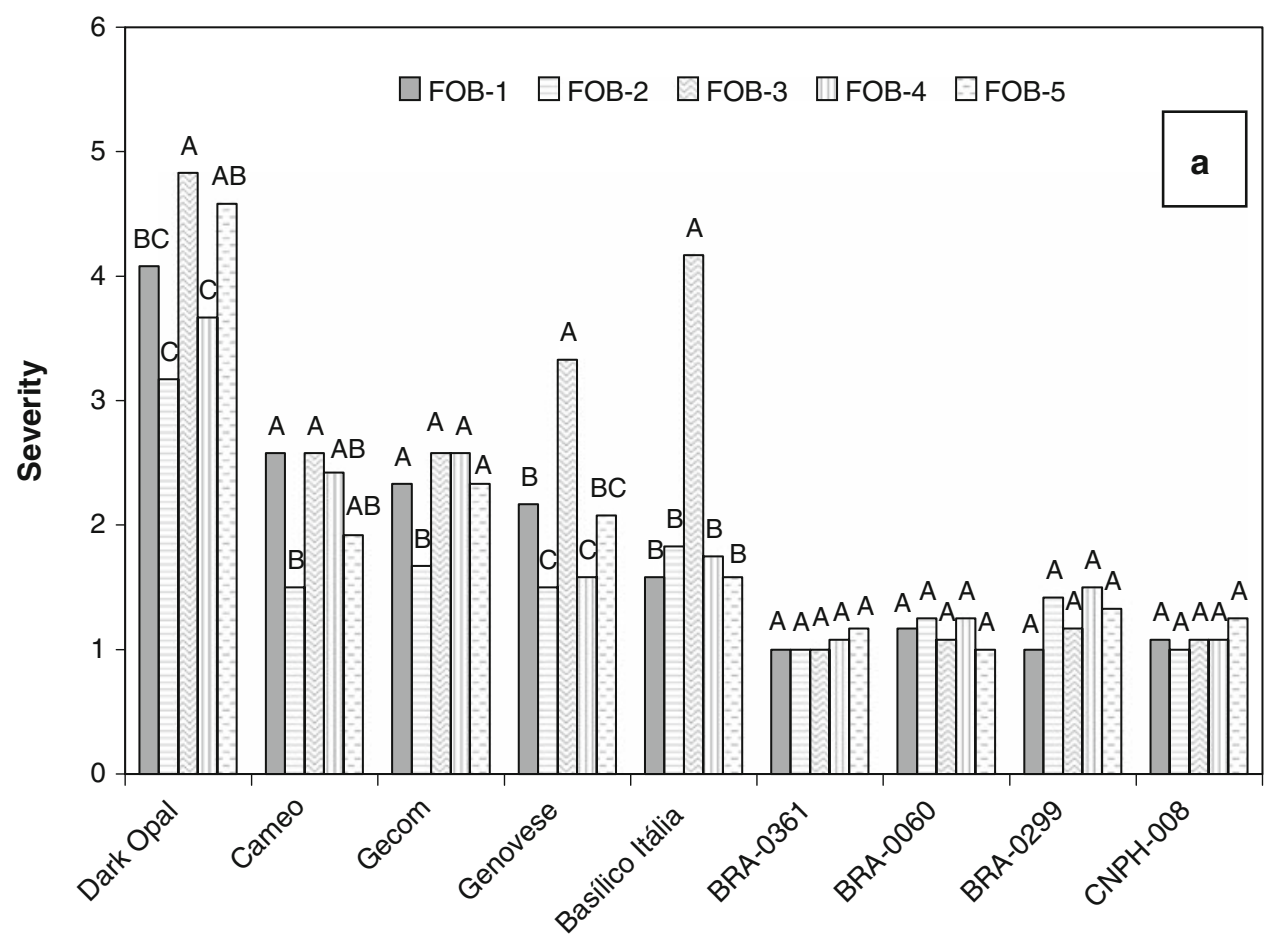

Ocimum Genotypes

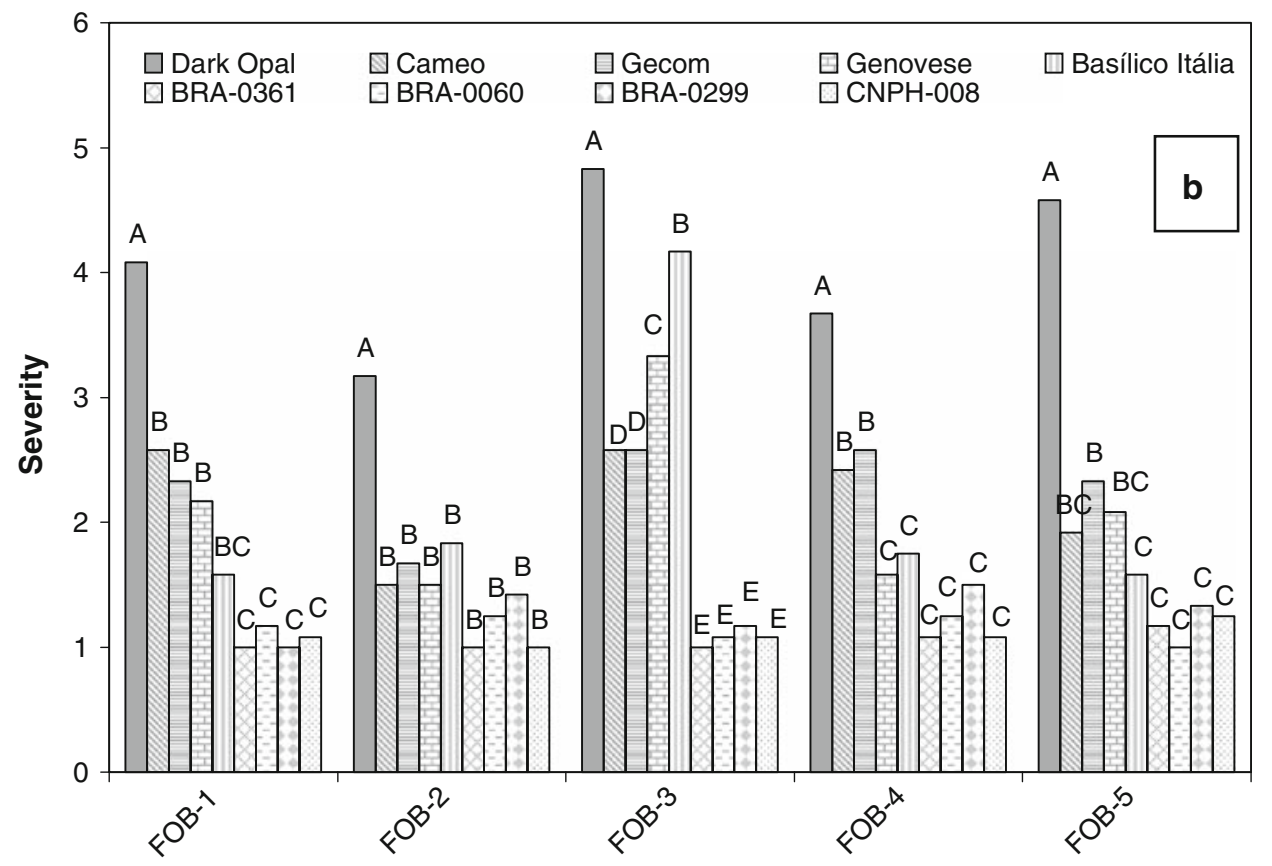

Pathogen Isolates also suggest that Brazilian and Greek isolates of the pathogen may differ in aggressiveness (or virulence profile).

The focus of the present work was to search for sources with wide-spectrum resistance (i.e., resistance effective against a range of FOB isolates of different origins). In fact, we found four accessions with a quasi-immune response to all five isolates, but our experiment does not represent a definitive answer about the presence of FOB races. We were able to identify a set of potential differential cultivars/accessions that might be useful for largescale analysis of fungal isolates to look for the presence of physiological races in the Ocimum-FOB pathosystem. Additional studies with a larger set of isolates from distinct geographical areas throughout the world could be helpful 
in clarifying these observations. If confirmed, FOB race variability might be an additional challenge for breeding programs.

In the present work, we were able to identify sources of resistance to FOB in $O$. basilicum and in other closely related species belonging to sects. Ocimum and Gymnocimum. The most promising accessions for breeding purposes are BRA-0060 (O. americanum), BRA-0299 (O. basilicum), BRA-0361 (O. americanum), and CNPH-008' (O. campechianum), which might represent new sources of large-spectrum resistance against FOB isolates. Natural interspecific and intraspecific hybridization are involved in generating the large phenotypic variability observed in Ocimum, which includes numerous species, botanical varieties, cultivars and chemotypes (Vieira and Simon 2006). It is important to mention that accessions of the closely related species $O$. americanum and $O$. campechianum could play an important role in broadening the genetic diversity of resistance alleles to FOB, if the natural crossing barriers among these species and $O$. basilicum can be overcome, as might happen with $O$. basilicum and $O$. americanum crosses because both belong to sect. Ocimum. However, in relation to O. campechianum, obtaining viable progeny may be more complicated because this species belongs to a more distantly related taxon (sect. Gymnocimum) (reviewed in Paton 1992; Albuquerque and Andrade 1998). Therefore, the introgression of resistance factors among accessions of Ocimum distinct species via classical hybridization methods would be very difficult. The interspecific transferring of gene(s) controlling high levels of resistance might be done via either cell biology techniques (e.g., embryo rescue) or transgenic approaches, which methods are currently in the process of optimization for Ocimum (Deschamps and Simon 2002).

Inheritance studies previously indicated that a single dominant gene (locus) is associated with the resistance of the cv. Nufar to an Israeli isolate of FOB (Dudai et al. 2002; Chaimovitsh et al. 2006). Similar inheritance studies would be necessary also to clarify the genetic basis and the mechanisms of the resistance in the majority of the largespectrum sources reported here. Breeding for disease resistance will be facilitated if the large-spectrum resistance to distinct FOB isolates reported here would also be under the control of a single dominant gene as in Nufar (Dudai et al. 2002; Chaimovitsh et al. 2006). However, to our knowledge, there is no information so far about the spectrum and stability of the resistance identified in Nufar. Unfortunately, seeds of Nufar were not available for evaluation in the present study, so we are interested in checking Nufar for resistance to other FOB isolates around the world.

There are many gaps in our understanding about FOB variability and a better characterization of its virulence and/or aggressiveness profile is crucial in breeding cultivars with wide-spectrum resistance. The employment of FOB-resistant varieties and hybrids seems to be a necessary strategy to make this crop economically viable in Brazil because the recent introduction of very destructive isolates. Furthermore, the chemical and cultural control measures against Fusarium wilt diseases are either expensive or not effective in most situations.

The work reported here is the first effort toward the introduction, maintenance and characterization of Ocimum germplasm to develop FOB-resistant cultivars adapted to Brazilian conditions. This effort is highly strategic as $O$. basilicum cultivation increases in economic and social importance in Brazil (Silva et al. 2005).

\section{References}

Albuquerque UP, Andrade LHC (1998) El género Ocimum L. (Lamiaceae) en el nordeste del Brasil. An Jard Bot Madr 56:43-64 (in Spanish)

Biris D, Vakalounakis DJ, Klironomou E (2004) Fusarium wilt of basil in Greece: Foliar infection and cultivar evaluation for resistance. Phytoparasitica 32:160-166

Chaimovitsh D, Dudai N, Putievsky E, Ashri A (2006) Inheritance of resistance to Fusarium wilt in sweet basil. Plant Dis 90:58-60

Deschamps C, Simon J (2002) Agrobacterium tumefaciens-mediated transformation of Ocimum basilicum and O. citriodorum. Plant Cell Rept 21:359-364

Dudai N, Chaimovitsh D, Reuveni R, Ravid U, Larkov O, Putievsky E (2002) Breeding of sweet basil (Ocimum basilicum) resistant to Fusarium wilt caused by Fusarium oxysporum f.sp. basilicum. J Herbs Spices Med Plants 9:45-51

Elmer WH (2001) Seeds as vehicles for pathogen importation. Biol Invasions 3:263-271

Garibaldi A, Gullino ML, Minuto G (1997) Diseases of basil and their management. Plant Dis 81:124-132

Grasso DS (1975) Un vvizzimento del basilico de Fusarium oxysporum. Infor Fitopatol 25:5-7 (in Italian)

Guirado-Moya ML, Gómez-Vázquez J, Blanco-Prieto R, TelloMarquina JC (2002) First report of Fusarium oxysporum f. sp. basilici in sweet basil cultivation in Spain. Plant Dis 86:1402

Katan T, Katan J, Ganliel A, Yunes H (1994) Fusarium disease of sweet basil. Phytoparasitica 22:89

Keinath AP (1994) Pathogenicity and host range of Fusarium oxysporum from sweet basil and evolution of disease control. Plant Dis 78:1211-1215

Nelson RR (1978) Genetics of horizontal resistance to plant diseases. Annu Rev Phytopathol 16:359-378

Özcan M, Chalchat JC (2002) Essential oil composition of Ocimum basilicum L. and Ocimum minimum L. in Turkey. Czech J Food Sci 20:223-228

Parlevliet JE (1979) Components of resistance that reduce the rate of epidemic development. Annu Rev Phytopathol 17:203-222

Paton A (1992) A synopsis of Ocimum L. (Labiatae) in Africa. Kew Bull 47:403-435

Reis A, Giordano LB, Lopes CA, Boiteux LS (2004) Novel sources of multiple resistance to three races of Fusarium oxysporum f. sp. lycopersici in Lycopersicon germplasm. Crop Breed App Biotech 4:495-502

Reis A, Miranda BEC, Boiteux LS, Henz GP (2007) Murcha do manjericão (Ocimum basilicum) no Brasil: agente causal, círculo 
de plantas hospedeiras e transmissão via semente. Summa Phytopathol 33:137-141 (in Portuguese)

Reuveni R, Dudai N, Putievsky E, Elmer WH, Wick RL (1997) Evaluation and identification of basil germ plasm for resistance to Fusarium oxysporum f. sp. basilici. Plant Dis 81:1077-1081

Ryding O (1994) Notes on the sweet basil and its wild relatives (Lamiaceae). Econ Bot 48:65-67

Silva F, Santos RHS, Andrade NJ, Barbosa LCA, Casali VWD, Lima RR, Passarinho RVM (2005) Basil conservation affected by cropping season, harvest time and storage period. Pesq Agropec Bras 40:323-328

Scott AJ, Knott M (1974) A cluster analysis method for grouping means in the analysis of variance. Biometrics 30:507-512
Summerell BA, Gunn LV, Bullock S, Tesoriero LT, Burgess LW (2006) Vascular wilt of basil in Australia. Australas Plant Pathol 35:65-67

Swart L, van Niekerk JM (2003) First record of Fusarium oxysporum f. sp. basilici occurring in sweet basil in South Africa. Australas Plant Pathol 32:125-126

Vieira RF, Simon JE (2000) Chemical characterisation of basil (Ocimum bsilicum L.) found in markets and used in traditional medicine in Brazil. Econ Bot 54:207-216

Vieira RF, Simon JE (2006) Chemical characterization of basil (Ocimum spp.) based on volatile oils. Flavor Fragr J 21:214-221

Wick RL, Haviland P (1992) Occurrence of Fusarium wilt of basil in the United States. Plant Dis 76:323 